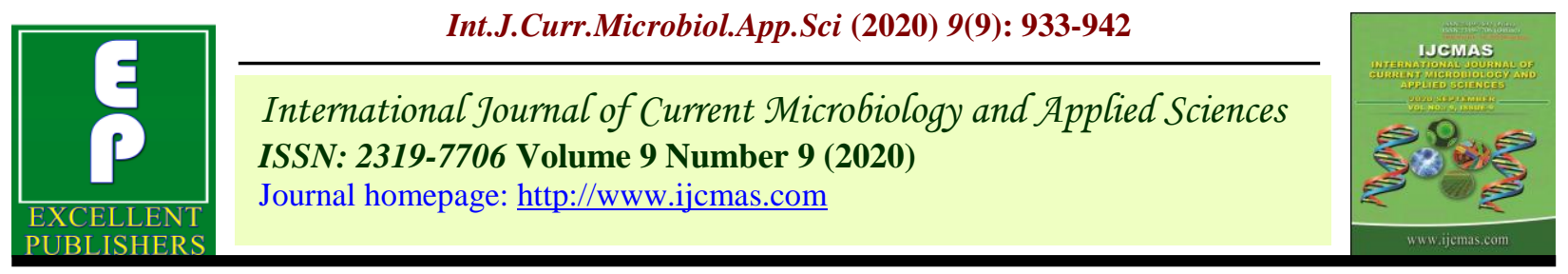

\title{
Effect of Varieties, Dates of Sowing, Growth Regulators and their Interaction on Growth and Yield of Dolichos Bean (Lablab purpureus L.) During off Season under Coastal Andhra Pradesh Conditions
}

\author{
E. Padma* K. Uma Jyothi, G. Ramanandam, P. Subbaramamma and K. Uma Krishna
}

Department of vegetable Science, College of Horticulture, Venkataramannagudem, West Godavari Dt.534101, Andhra Pradesh, India

*Corresponding author

\section{A B S T R A C T}

\begin{tabular}{l} 
Ke y w o r d s \\
$\begin{array}{l}\text { Dolichos Bean, } \\
\text { (Lablab } \\
\text { purpureus L.) }\end{array}$ \\
Article Info \\
$\begin{array}{l}\text { Accepted: } \\
10 \text { August } 2020 \\
\text { Available Online: } \\
10 \text { September } 2020\end{array}$ \\
\hline
\end{tabular}

Keywords

Dolichos Bean,

(Lablab

purpureus L.)

Article Info

Accepted:

Available Online:

10 September 2020
The present investigation entitled "Effect of varieties, dates of sowing, growth regulators on growth and yield of Dolichos Bean (Lablab purpureus L.) during offseason under coastal Andhra Pradesh conditions was carried out during summer 2014-15 and 2015-16 at Horticultural Research Station, Ambajipeta, East Godavari District of Andhra Pradesh. The experiment was laid out with 36 different treatment combinations in a Factorial Randomized Block Design (FRBD) each replicated thrice in open field. The experiment was carried out with four varieties viz., Arka Jay, Arka Amog, Arka Sambhram and Arka Sowmya with three different dates of sowing viz., December $15^{\text {th }}$, January $1^{\text {st }}$ and January $15^{\text {th }}$ with foliar spray of growth regulators viz., NAA $25 \mathrm{ppm}$, Triacontanol $2 \mathrm{ppm}$ and control. The data were recorded on various growth, and yield parameters and the data were statistically analyzed based on ANOVA. Arka Sowmya $\left(\mathrm{V}_{4}\right)$ recorded significantly highest leaf area $\left(1113.8 \mathrm{~cm}^{2}\right)$ number of buds per node $(5.07)$, pod weight $(4.54 \mathrm{~g})$ and highest pod yield per ha $(197.36 \mathrm{q})$ in open field. Arka Jay took least number of days for 50 per cent flowering (41.62 days). January $1^{\text {st }}$ sown crop recorded significantly the highest plant height $(67.77 \mathrm{~cm})$, leaf area $\left(1113.8 \mathrm{~cm}^{2}\right)$ number of buds per node $(4.81)$ and highest pod yield per ha (204.43q) and also took less number of days for 50 per cent flowering (41.02) in open field . Triacontanol @2 pm foliar spray recorded significantly the highest plant height $(68.4 \mathrm{~cm})$, leaf area $\left(1077.0 \mathrm{~cm}^{2}\right)$, number of buds per node $(4.87)$ and pod yield(190.1q/ha) and took least number of days to $50 \%$ flowering (41.64 days). Arka Sowmya recorded the highest pod yield per hectare (262.12q) when sown on January $1^{\text {st }}$ and sprayed with Triacontanol 2 ppm foliar spray $\left(\mathrm{V}_{4} \mathrm{~S}_{2} \mathrm{G}_{2}\right)$.

\section{Introduction}

In India, Lablab is a field crop mostly confined to the peninsular region and is cultivated to a large extent in Karnataka and adjoining districts of Tamil Nadu, Andhra Pradesh and Maharashtra. Karnataka contributes a major share, accounting for nearly 90 per cent in terms of both area and production in the country. In Andhra Pradesh, beans are cultivated in an area of 228000 ha with a production of 2277000 MT (National Horticulture Board Statistics 2017-18). The normal growing seasons for field bean are 
Kharif and Rabi. The beans are not available in Andhra Pradesh after February month. By growing beans in off season i.e., summer, the produce will be made available to the consumers all throughout the year and also the farmers can fetch better price for their produce. Among the agronomic practices, optimum sowing time is considered as an important non-cash input, results in considerable increase in the yield and quality. Productivity in most of the vegetable crops depends on prevailing environmental conditions to which phenological stages of the crop are being exposed. The staggered dates of sowing may thus influence the crop growth, flowering and yield. The plant growth regulators are either natural or synthetic compounds applied to the target plants to modify either developmental or morphological structure or both by manipulating the hormonal levels in different plant organs at various growth stages of the plant in the life cycle so as to enhance its yield and quality (Setia et al., 1991). The information on suitable varieties, optimum sowing date and growth regulators on off season production of field bean is scanty. Hence, the present study is conducted to find out the field bean varieties suitable for growing in off season for coastal Andhra Pradesh in open field with optimum date of sowing and suitable growth regulator.

\section{Materials and Methods}

The investigation entitled "Effect of varieties, dates of sowing, growth regulators and their interaction on growth and yield of Dolichos Bean (Lablab purpureus L.) during offseason under coastal Andhra Pradesh conditions " was carried out during summer 2014-15 and 2015-16 at Horticultural Research Station, Ambajipeta, East Godavari District of Andhra Pradesh which is situated at $16.4^{0} \mathrm{~N}$ latitude and $81.5^{\circ} \mathrm{E}$ longitudes with an altitude of 34 $\mathrm{m}$ above mean sea level. The experimental site receives an annual rainfall of $1186 \mathrm{~mm}$. The $\mathrm{pH}$ of irrigated water was 7.3 and EC is of $0.7 \mathrm{dSm}^{-1}$. The experiment was laid out with 36 different treatment combinations in a Factorial Randomized Block Design (FRBD) each replicated thrice in open field. The experiment was carried out with four varieties viz., Arka Jay $\left(\mathrm{V}_{1}\right)$, Arka $\operatorname{Amog}\left(\mathrm{V}_{2}\right)$, Arka Sambhram $\left(\mathrm{V}_{3}\right)$ and Arka Sowmya $\left(\mathrm{V}_{4}\right)$ with three different dates of sowing viz., December $15^{\text {th }}\left(\mathrm{S}_{1}\right)$ January $^{\text {st }}\left(\mathrm{S}_{2}\right)$ and January $15^{\text {th }}\left(\mathrm{S}_{3}\right)$ with foliar spray of growth regulators viz., NAA 25 ppm $\left(G_{1}\right)$, Triacontanol 2 ppm $\left(G_{2}\right)$, and control $\left(\mathrm{G}_{3}\right)$. Growth regulators were sprayed at 30 DAS and 60 DAS. The experimental area was thoroughly ploughed and brought into a fine tilth. Recommended dose of FYM and basal dose of fertilizers were incorporated into the soil before the final ploughing. The recommended dose of $\mathrm{N}, \mathrm{P}$ and $\mathrm{K}$ (20:60:50 $\mathrm{kg}$ per ha) were applied in the form of urea, single super phosphate and muriate of potash respectively. Nitrogen was applied in 2 splits, half of the nitrogen (i.e. 10 $\mathrm{kg}$ ) was applied as basal dose and the remaining half of the nitrogen (i.e. $10 \mathrm{~kg}$ ) was applied as top dressing at 30 days after sowing. The entire dose of phosphorus and potash were applied at the time of sowing as basal dose. The various observations on growth and yield parameters were recorded on five plants which were tagged. Days to $50 \%$ flowering was calculated as number of days taken from the date of sowing to the day when 50 per cent of the plants in a plot were flowered. The two years data were recorded on various growth and yield parameters and the pooled data were statistically analyzed based on ANOVA.

\section{Results and Discussion}

The data regarding the effect of sowing time and growth regulators and their interaction on growth characters of field bean varieties under open field condition was presented in 
Table 1. Non significant differences were found among the field bean varieties for plant height at harvest. Regarding sowing time, January $1^{\text {st }}$ sown crop recorded the highest plant height $(67.77 \mathrm{~cm})$ followed by January $15^{\text {th }}$ sown crop $(67.31 \mathrm{~cm})$ and December $15^{\text {th }}$ sown crop $(66.56 \mathrm{~cm})$. The January $1^{\text {st }}$ sown crop recorded highest plant height which might be due to prevailing environmental conditions especially photoperiod and temperature prevailed during vegetative growth. The results are in agreement with the findings of Patel et al., (2008) in moth bean and Joshi and Rahevar (2014) in Indian bean. Growth regulators significantly influenced the plant height at harvest. At harvest, significantly highest plant height $(68.41 \mathrm{~cm})$ was observed with Triacontanol 2 ppm spray $\left(\mathrm{G}_{2}\right)$ and the lowest plant height $(65.90 \mathrm{~cm})$ was observed without growth regulator spray (control treatment). The increase in plant height by foliar application of $2 \mathrm{ppm}$ Triacontanol could be attributed to an enhanced cell division. Similar results were reported by Chaudhary et al., (2006) in chilli and Singh (2010) in fenugreek.

The interaction between varieties and dates of sowing showed significant effect on plant height at harvest. At harvest, Arka Sambhram recorded the highest plant height $(68.31 \mathrm{~cm})$ when sown on January $1^{\text {st }}\left(\mathrm{V}_{3} \mathrm{~S}_{2}\right)$ and Arka Sambhram recorded the lowest plant height $(65.55 \mathrm{~cm})$ when sown on December $15^{\text {th }}$ $\left(\mathrm{V}_{3} \mathrm{~S}_{1}\right)$. The field bean varieties Arka Jay, Arka Sowmya and Arka Sambhram performed well when sown on January $1^{\text {st }}$ than sown on December $15^{\text {th }}$ and January $15^{\text {th }}$. The interaction between varieties and growth regulators, sowing dates and growth regulators, varieties, dates of sowing and growth regulators showed non significant effect on plant height at harvest.

With regard to leaf area per plant, the data was found significant with different varieties, dates of sowing and growth regulators and their interactions. Arka Sowmya $\left(\mathrm{V}_{4}\right)$ recorded significantly highest leaf area per plant $\left(1065.9 \mathrm{~cm}^{2}\right)$ at harvest whereas, Arka Jay $\left(\mathrm{V}_{1}\right)$ recorded lowest leaf area $\left(910.2 \mathrm{~cm}^{2}\right)$ Similar results have been reported Esakkiammal et al., (2015) in dolichos bean and Prakash et al., (2015) in french bean. Significant differences were noticed among the dates of sowing with regard to leaf area per plant. Significantly highest leaf area per plant (1028.3 $\mathrm{cm}^{2}$ at harvest) was observed with January $1^{\text {st }}$ sowing $\left(\mathrm{S}_{1}\right)$ whereas, the lowest leaf area per plant $\left(975.7 \mathrm{~cm}^{2}\right)$ at harvest was observed with January $15^{\text {th }}$ sowing $\left(\mathrm{S}_{3}\right)$. Sowing of field bean on January $1^{\text {st }}$ recorded maximum leaf area per plant when compared to other dates of sowing might be due to presence of favourable environmental conditions such as temperature, day length and light intensity during this period. Similar results were obtained Abido and Seadh (2014) in dolichos bean.The influence of growth regulators on leaf area per plant was also significant. Significantly the highest leaf area $\left(1077.0 \mathrm{~cm}^{2}\right.$ at harvest) was recorded with Triacontanol 2 ppm whereas, lowest leaf area $\left(933.0 \mathrm{~cm}^{2}\right.$ at harvest) was recorded in control. The increase in leaf area due to Triacontanol foliar spray may be attributed to an increase in meristematic activity of leaf primordia.

The interaction between varieties and sowing dates was found significant with respect to leaf area per plant. Significantly the highest leaf area per plant $\left(1113.8 \mathrm{~cm}^{2}\right.$ at harvest) was recorded by Arka Sowmya with January $15^{\text {th }}$ sowing $\left(\mathrm{V}_{4} \mathrm{~S}_{3}\right)$. Significant interaction was observed between varieties and growth regulators with respect to leaf area per plant. Significantly the highest leaf area per plant at harvest $\left(1142.6 \mathrm{~cm}^{2)}\right.$ was observed by Arka Sowmya sprayed with Triacontanol @ 2ppm $\left(\mathrm{V}_{4} \mathrm{G}_{2}\right)$ whereas, lowest leaf area $\left(779.5 \mathrm{~cm}^{2}\right.$ at harvest respectively) was observed by Arka 
Jay without growth regulator spray $\left(\mathrm{V}_{1} \mathrm{G}_{3}\right)$. No significant differences for leaf area were observed at harvest among SxG interactions. Among $\mathrm{VxSxG}$ interactions, Arka Sowmya sown on January $15^{\text {th }}$ with Triacontanol 2 ppm foliar spray $\left(\mathrm{V}_{4} \mathrm{~S}_{3} \mathrm{G}_{2}\right)$ recorded the highest leaf area per plant $\left(1148.71 \mathrm{~cm}^{2}\right)$.

Varieties, dates of sowing, growth regulators and their interactions showed significant effect on number of buds per node and days to $50 \%$ flowering and the data are presented in Table 2. The effect of variety on number of buds per node was significant. The highest number of buds per node was observed in Arka Sowmya $\left(\mathrm{V}_{4}\right)$ (5.07) and the lowest in Arka Sambhram $\left(\mathrm{V}_{3}\right)$ (4.38). The variation in number of buds per node among the varieties could be attributed to their inherent genetic character and influence of environmental factors. Similar variation in number of buds per node was reported by Das et al., (2012) in country bean. The effect of dates of sowing on number of buds per node was also significant. The highest number of buds per node were observed in January $1^{\text {st }}$ sown crop $\left(\mathrm{S}_{2}\right)$ (4.81) and was on par with December $15^{\text {th }}$ sown crop $\left(\mathrm{S}_{1}\right)$ (4.80). The field bean crop sown on January $15^{\text {th }}\left(\mathrm{S}_{3}\right)$ recorded the lowest number of buds per node (4.25).The highest number of buds per node in January $1^{\text {st }}$ sown crop could be attributed to the presence of congenial climatic factors for formation of buds when compared with other dates of sowing.

The effect of growth regulators on number of buds per node was significant. The plants sprayed with Triacontanol $2 \mathrm{ppm}\left(\mathrm{G}_{2}\right)$ recorded the highest number of buds per node (4.87), followed by NAA 25 ppm spray (4.55) and control (4.44). The growth regulators significantly influenced the number of buds per node. It might be due to an increased photo assimilates and improved translocation of food assimilates to the meristematic tissue at nodal region and differentiation of meristematic tissue into flower buds.

The effect of $\mathrm{VxS}$ interaction was significant for number of buds per node. The highest number of buds per node were observed in Arka Sowmya sown on January $15^{\text {th }}\left(\mathrm{V}_{4} \mathrm{~S}_{3}\right)$ (5.33) and was on par with Arka Sowmya sown on January $1^{\text {st }}(5.18)$ Arka Sambhram (5.10) sown on December $15^{\text {th }}\left(\mathrm{V}_{3} \mathrm{~S}_{1}\right)$. The effect of $\mathrm{VxG}$ interaction was significant for number of buds per node. The highest number of buds per node (5.34) was observed in Arka Sowmya in combination with Triacontanol 2 ppm spray $\left(\mathrm{V}_{4} \mathrm{G}_{2}\right)$. The lowest number of buds per node (4.15) was observed in Arka Sambhram without spray $\left(\mathrm{V}_{3} \mathrm{G}_{3}\right)$. The effect of SxG interaction was non-significant for number of buds per node. The effect of $\mathrm{VxSxG}$ was found significant for number of buds per node. The highest number of buds per node were observed in Arka Sowmya sown on January $15^{\text {th }}$ in combination with Triacontanol 2 ppm spray $\left(\mathrm{V}_{4} \mathrm{~S}_{3} \mathrm{G}_{2}\right)$ (5.71).

The varieties differed significantly for days to 50 per cent flowering. Arka Jay took less number of days to 50 per cent flowering (41.62 days) whereas, Arka Sowmya took more number of days to 50 per cent flowering (43.10 days). The variety, Arka Jay flowered earlier in the present study. The earliness in Arka Jay could be due to earlier morphological differentiation due to its inherent genetic factor and better adaptability to growing environmental conditions. Similar variation in days to 50 per cent flowering has been earlier reported by Rana and Kumar (2008) in french bean and Prakash and Ram (2014) in french bean and Kharbamon et al., (2016) in Indian bean.The influence of dates of sowing on days to 50 per cent flowering was significant. January $1^{\text {st }}$ sowing took less number of days for 50 per cent flowering (41.02), followed by January $15^{\text {th }}$ sowing (41.99 days) and December $15^{\text {th }}$ sowing (43.54). 
Table.1 Effect of varieties, dates of sowing, growth regulators and their interaction on plant height in field bean at 90 DAS and at harvest in open field

\begin{tabular}{|c|c|c|c|c|c|c|c|c|c|c|c|}
\hline \multirow{3}{*}{\multicolumn{2}{|c|}{ Varieties (V) }} & \multirow{2}{*}{\multicolumn{4}{|c|}{$\begin{array}{c}\text { Plant Height }(\mathrm{cm}) \text { at harvest } \\
\text { Dates of sowing }(\mathrm{S})\end{array}$}} & \multicolumn{6}{|c|}{ Leaf area par plant at harvest $\left(\mathrm{cm}^{2}\right)$} \\
\hline & & & & & & \multicolumn{6}{|c|}{ Dates of sowing (S) } \\
\hline & & $\mathbf{S}_{1}$ & $\mathbf{S}_{\mathbf{2}}$ & $\mathbf{S}_{3}$ & Mean & \multicolumn{2}{|c|}{ Varieties (V) } & $\mathbf{S}_{1}$ & $\mathbf{S}_{\mathbf{2}}$ & $\mathbf{S}_{3}$ & Mean \\
\hline \multicolumn{2}{|l|}{$V_{1}$} & 67.27 & 67.08 & 67.33 & 67.23 & $\mathrm{~V}_{1}$ & & 854.4 & 1013.4 & 862.9 & 910.2 \\
\hline \multicolumn{2}{|l|}{$\mathbf{V}_{2}$} & 67.16 & 67.71 & 67.30 & 67.39 & $\mathrm{~V}_{2}$ & & 1055.2 & 1104.1 & 1016.7 & 1058.7 \\
\hline \multicolumn{2}{|l|}{$V_{3}$} & 65.55 & 68.31 & 67.80 & 67.22 & $\mathrm{~V}_{3}$ & & 1068.6 & 995.9 & 909.3 & 991.3 \\
\hline \multicolumn{2}{|l|}{$\mathbf{V}_{4}$} & 66.27 & 66.99 & 66.80 & 67.02 & $\mathrm{~V}_{4}$ & & 1083.9 & 999.9 & 1113.8 & 1065.9 \\
\hline \multicolumn{2}{|l|}{ Mean } & 66.56 & 67.77 & 67.31 & -- & Mea & & 1015.5 & 1028.3 & 975.7 & -- \\
\hline \multirow{2}{*}{\multicolumn{2}{|c|}{ Varieties (V) }} & \multicolumn{3}{|c|}{ Growth Regulators (G) } & \multirow[t]{2}{*}{ Mean } & \multirow{2}{*}{\multicolumn{2}{|c|}{ Varieties (V) }} & \multicolumn{3}{|c|}{ Growth Regulators (G) } & \multirow{2}{*}{ Mean } \\
\hline & & $\mathbf{G}_{1}$ & $\mathbf{G}_{2}$ & $\mathbf{G}_{3}$ & & & & $\mathbf{G}_{1}$ & $\mathbf{G}_{2}$ & $\mathbf{G}_{3}$ & \\
\hline \multicolumn{2}{|l|}{$V_{1}$} & 67.27 & 68.34 & 66.08 & 67.23 & $\mathrm{~V}_{1}$ & & 940.2 & 1011.0 & 779.5 & 910.2 \\
\hline \multicolumn{2}{|l|}{$\mathbf{V}_{2}$} & 67.47 & 68.72 & 65.99 & 67.39 & $\mathrm{~V}_{2}$ & & 1066.7 & 1102.7 & 1006.5 & 1058.7 \\
\hline \multicolumn{2}{|l|}{$\mathbf{V}_{3}$} & 67.29 & 68.43 & 65.94 & 67.22 & $\mathrm{~V}_{3}$ & & 983.0 & 1049.9 & 940.9 & 991.3 \\
\hline \multicolumn{2}{|l|}{$V_{4}$} & 67.33 & 68.13 & 65.60 & 67.02 & $\mathrm{~V}_{4}$ & & 1049.5 & 1142.6 & 1005.5 & 1065.9 \\
\hline \multicolumn{2}{|l|}{ Mean } & 67.34 & 68.41 & 65.90 & -- & Mea & & 1010.0 & 1077.0 & 933.0 & -- \\
\hline \multirow{2}{*}{\multicolumn{2}{|c|}{ Dates of sowing(S) }} & Grov & n Regula & $\operatorname{rs}(\mathbf{G})$ & Mean & Date & & Growt & h Regulat & ors (G) & Mean \\
\hline & & $\mathbf{G}_{1}$ & $\mathbf{G}_{2}$ & $\mathbf{G}_{3}$ & & sowi & & $\mathbf{G}_{1}$ & $G_{2}$ & $\mathbf{G}_{3}$ & \\
\hline$S_{1}$ & & 66.71 & 67.51 & 65.47 & 66.56 & $\mathrm{~S}_{1}$ & & 1013.0 & 1083.0 & 951.0 & 1015.5 \\
\hline $\mathbf{S}_{2}$ & & 67.76 & 69.26 & 66.31 & 67.77 & $\mathrm{~S}_{2}$ & & 1024.0 & 1106.0 & 955.0 & 1028.3 \\
\hline $\mathbf{S}_{3}$ & & 67.56 & 68.45 & 65.92 & 67.31 & $\mathrm{~S}_{3}$ & & 992.0 & 1041.0 & 893.0 & 975.7 \\
\hline Mean & & 67.34 & 68.41 & 65.90 & -- & Mea & & 1010.0 & 1077.0 & 933.0 & -- \\
\hline Interact & (VxSxG) & Grov & Aegul & $\mathrm{rs}(\mathbf{G})$ & & Inte & & Growt & h Regulat & ors (G) & \\
\hline & & $\mathbf{G}_{1}$ & $\mathbf{G}_{2}$ & $\mathbf{G}_{3}$ & & $(\mathbf{V x}$ & & $\mathbf{G}_{1}$ & $\mathbf{G}_{2}$ & $\mathbf{G}_{3}$ & \\
\hline$V_{1}$ & $S_{1}$ & 67.55 & 68.66 & 65.60 & -- & $\mathrm{V}_{1}$ & $\mathrm{~S}_{1}$ & 881.29 & 971.16 & 710.85 & -- \\
\hline & $\mathbf{S}_{2}$ & 66.51 & 68.86 & 65.89 & -- & & $\mathbf{S}_{2}$ & 1060.74 & 1121.39 & 858.04 & -- \\
\hline & $\mathbf{S}_{3}$ & 67.76 & 67.51 & 66.74 & -- & & $\mathbf{S}_{3}$ & 878.65 & 940.53 & 769.55 & -- \\
\hline $\mathbf{V}_{2}$ & $S_{1}$ & 67.09 & 68.11 & 66.28 & -- & $\mathrm{V}_{2}$ & $S_{1}$ & 1056.52 & 1076.97 & 1032.01 & -- \\
\hline & $\mathbf{S}_{2}$ & 67.99 & 69.64 & 65.50 & -- & & $\mathbf{S}_{2}$ & 1099.93 & 1132.27 & 1080.07 & -- \\
\hline & $\mathbf{S}_{3}$ & 67.31 & 68.41 & 66.18 & -- & & $\mathbf{S}_{3}$ & 1043.72 & 1098.99 & 907.41 & -- \\
\hline $\mathbf{V}_{3}$ & $S_{1}$ & 65.76 & 66.05 & 64.84 & -- & $\mathrm{V}_{3}$ & $S_{1}$ & 1034.88 & 1051.63 & 1019.15 & -- \\
\hline & $\mathbf{S}_{2}$ & 68.06 & 69.74 & 67.14 & -- & & $\mathbf{S}_{2}$ & 982.5 & 1021.81 & 983.30 & -- \\
\hline & $S_{3}$ & 68.06 & 69.49 & 65.84 & -- & & $\mathbf{S}_{3}$ & 931.72 & 976.20 & 820.10 & -- \\
\hline$V_{4}$ & $S_{1}$ & 66.44 & 67.22 & 65.16 & -- & $\mathrm{V}_{4}$ & $S_{1}$ & 1078.16 & 1131.74 & 1041.86 & -- \\
\hline & $\mathrm{S}_{2}$ & 68.46 & 68.81 & 66.70 & -- & & $\mathbf{S}_{2}$ & 954.52 & 1147.38 & 897.83 & -- \\
\hline & $\mathbf{S}_{3}$ & 67.09 & 68.37 & 64.94 & -- & & $\mathbf{S}_{3}$ & 1115.90 & 1148.71 & 1076.92 & -- \\
\hline Source & & SE.m \pm & & C.D & $5 \%$ & & & $m \pm$ & & C.D & $5 \%$ \\
\hline V & & 0.19 & & & & & & .49 & & & \\
\hline $\mathbf{S}$ & & 0.16 & & & & & & .08 & & & \\
\hline G & & 0.16 & & & & & & .08 & & & \\
\hline VxS & & 0.32 & & & & & & .17 & & & \\
\hline VxG & & 0.32 & & & & & & 3.17 & & & \\
\hline SxG & & 0.28 & & & & & & .74 & & & \\
\hline VxSxG & & 0.57 & & & & & & .48 & & & \\
\hline
\end{tabular}

Varieties (V)

$\mathrm{V}_{1}$. Arka Jay

$\mathrm{V}_{2}$ - Arka Amog

$\mathrm{V}_{3}$ - Arka Sambhram

$\mathrm{V}_{4}$ - Arka Sowmya
Dates of sowing (S)

$\mathbf{S}_{\mathbf{1}}$ - December $15^{\text {th }}$

$\mathbf{S}_{\mathbf{2}}$ - January $1^{\text {st }}$

$\mathbf{S}_{\mathbf{3}}$ - January $15^{\text {th }}$
Growth Regulators (G)

$\mathbf{G}_{1}$ - NAA $25 \mathrm{ppm}$

$\mathbf{G}_{\mathbf{2}}$ - Triacontanol $2 \mathrm{ppm}$

$\mathbf{G}_{3}$ - Control 
Table.2 Effect of varieties, dates of sowing, growth regulators and their interaction on number of buds/node and days to $50 \%$ flowering in field bean in open field

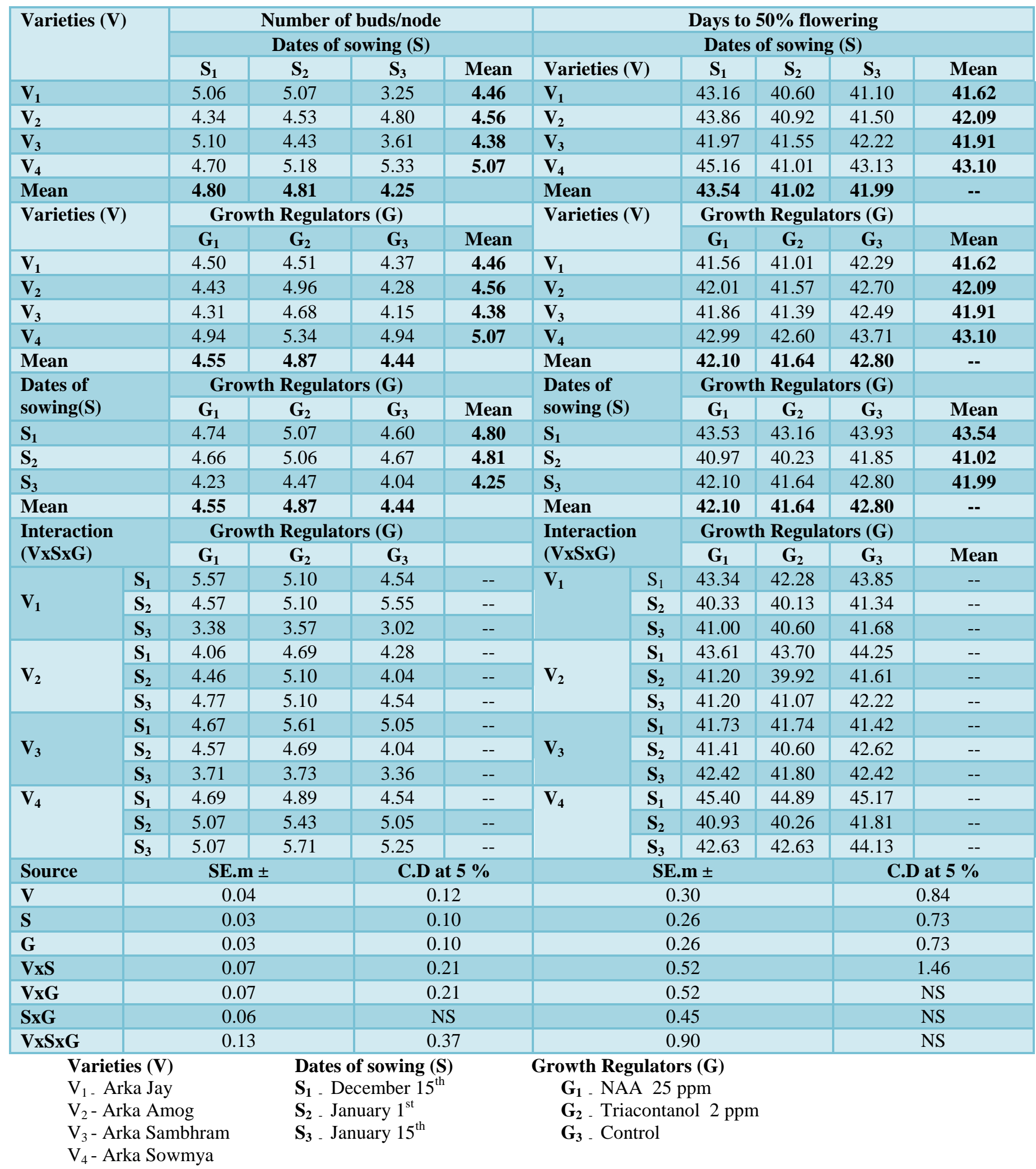


Table.3 Effect of varieties, dates of sowing, growth regulators and their interaction on pod weight and pod yield per hectare in field bean in open field

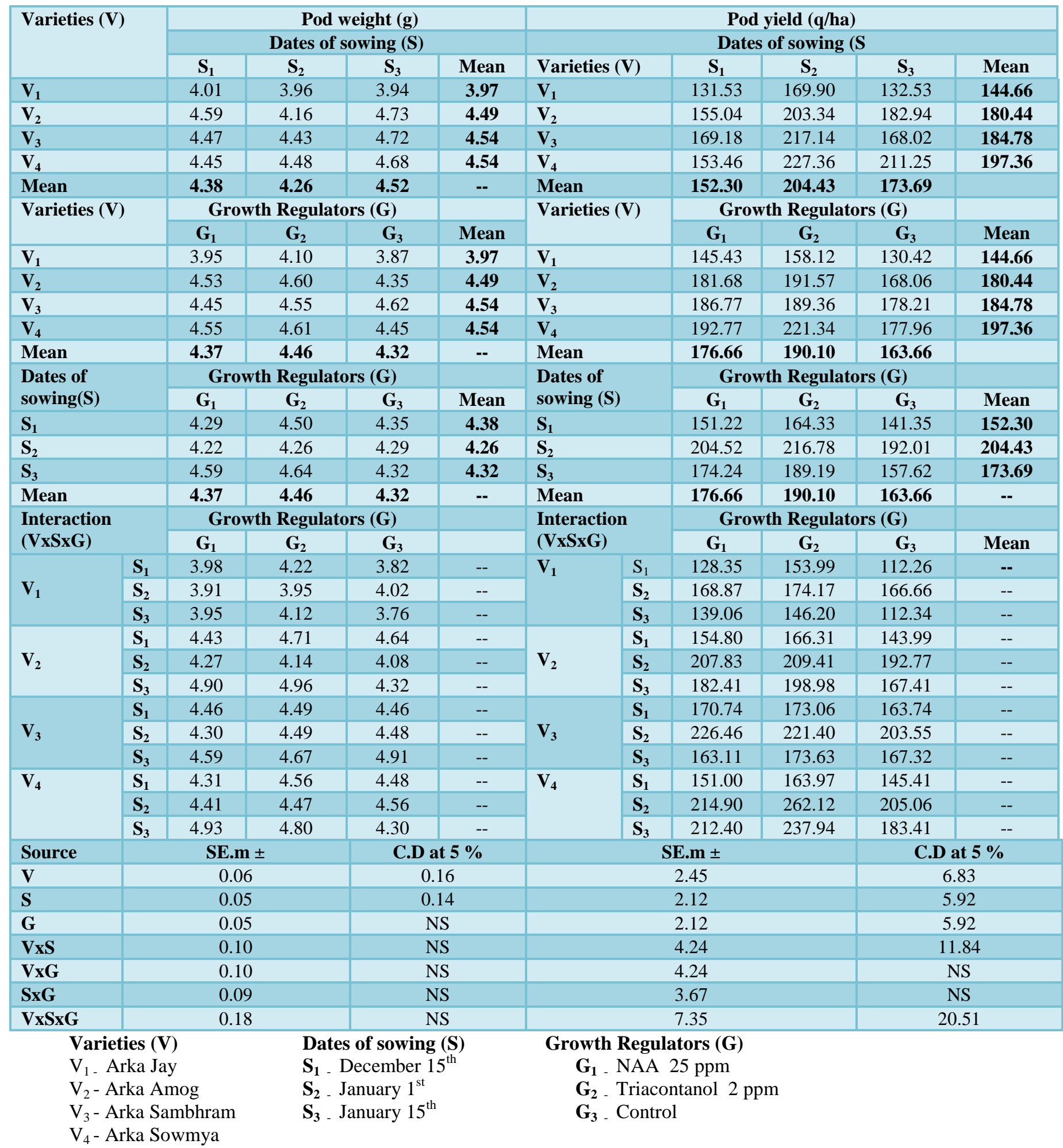


The reason for variation in days to 50 per cent flowering might be due to varied weather conditions prevailed during different sowing times as reported by Hussain (2005) and Surekha (2006) in french bean.The influence of growth regulators on days to 50 per cent flowering was significant. The plants sprayed with Triacontanol $2 \mathrm{ppm}$ spray took the lowest number of days to 50 per cent flowering (41.64 days) and it was on par with NAA 25 ppm (42.10 days) whereas, $\mathrm{G}_{3}$ (control) took the highest number of days (42.80). This can be attributed to the higher rate of photosynthesis and reduced respiration due to Triacontanol application which might have resulted in the early flowering. The results are in agreement with findings of Sharma (1995) in tomato.The interaction effect of $\mathrm{VxS}$ was significant for days to 50 per cent flowering Arka Jay when sown on January $1^{\text {st }}$ took less number of days to $50 \%$ flowering $\left(\mathrm{V}_{1} \mathrm{~S}_{2}\right)(40.60)$. The interactions effect of $\mathrm{VxG}, \mathrm{SxG}$ and $\mathrm{VxSxG}$ was nonsignificant for days to 50 per cent flowering.

Varieties and dates of sowing showed significant effect on pod weight. Growth regulators, interaction of varieties and sowing dates, sowing dates and growth regulators and varieties, sowing dates and growth regulators showed non significant effect on pod weight and the results are depicted in Table 3.

The highest pod weight (4.54 g) was noticed in Arka Sowmya $\left(\mathrm{V}_{4}\right)$ and Arka Sambhram $\left(\mathrm{V}_{3}\right)$. Pod weight was lowest in Arka Jay $\left(\mathrm{V}_{1}\right)$ $(3.97 \mathrm{~g})$. It might be due to the genotypic variation among the varieties and their interaction with environmental factors reaction which might have accelerated the vegetative and reproductive growth phases ultimately promoted pod weight. The present findings are in agreement with the findings of Patel et al., (2011), Ravinaik et al., (2012) in dolichos bean.
Dates of sowing showed significant effect on pod weight. The highest pod weight was noticed with January $15^{\text {th }}$ sowing $\left(\mathrm{S}_{3}\right)$ (4.52 $\mathrm{g})$, followed by December $15^{\text {th }}$ sowing $\left(\mathrm{S}_{1}\right)$ $(4.38 \mathrm{~g})$. January $1^{\text {st }}$ sowing $\left(\mathrm{S}_{1}\right)$ recorded the lowest pod weight $(4.26 \mathrm{~g})$. The variation in pod weight might be due to variation in climatic factors owing to different sowing times. The present results are in consonance with the findings of Abido and Seadh (2014) in dolichos bean.

Growth regulators showed non-significant effect on pod weight. The interactions of varieties and sowing dates, varieties and growth regulators, sowing dates and growth regulators and varieties, sowing dates and growth regulators also showed non-significant effect on pod weight.

The results on pod yield per hectare in field bean as influenced by varieties, dates of sowing and growth regulators are presented in Table 3. The varieties recorded significant differences for pod yield per hectare. Arka Sowmya $\left(\mathrm{V}_{4}\right)$ recorded significantly the highest pod yield per ha (197.36 q) followed by Arka Sambhram $\left(\mathrm{V}_{3}\right) \quad(184.78$ q).The increase in pod yield per hectare may be ascribed to the results of the present study which showed more leaf area and pod weight. Further, yield also depends on the genetic constitution of the variety. The findings are in corroborate with the results obtained by Sharma et al., (2014) and Prakash et al., (2015) in dolichos bean.

Dates of sowing showed significant influence on pod yield per hectare. The crop sown on January $1^{\text {st }}\left(S_{2}\right)$ recorded significantly the highest pod yield per hectare (204.43 q) followed by crop sown on January $15^{\text {th }}\left(\mathrm{S}_{3}\right)$ (173.69 q). Spraying of growth regulators showed significant influence on pod yield per hectare. Triacontanol $2 \mathrm{ppm}$ as foliar spray $\left(G_{2}\right)$ recorded the highest pod yield per 
hectare (190.1 q), followed by spraying of NAA $25 \mathrm{ppm}\left(\mathrm{G}_{1}\right)$ (176.66 q). The positive influence of Triacontanol on plant yield might be due to its impact on the carbon cycle in plant i.e., higher $\mathrm{CO}_{2}$ fixation and their efficient translocation to the sink (Menon and Srivastava, 1984). Similar results were reported by Singh (2010) in fenugreek and Palakshi et al., (2012) in tomato The interaction of varieties and sowing dates showed significant effect on pod yield per ha. Arka Sowmya recorded the highest pod yield per ha (227.36 q) when sown on January $1^{\text {st }}$ $\left(\mathrm{V}_{4} \mathrm{~S}_{2}\right)$ followed by Arka Sambhram with same date of sowing $\left(\mathrm{V}_{3} \mathrm{~S}_{2}\right)(217.14 \mathrm{q})$. Arka Jay recorded the lowest yield per ha (131.53 q) when sown on December $15^{\text {th }}\left(\mathrm{V}_{1} \mathrm{~S}_{1}\right)$. The interaction of varieties and growth regulators and interaction of sowing dates and growth regulators showed non significant influence on pod yield per hectare. The interaction of varieties, dates of sowing and growth regulators influenced the pod yield per ha significantly. Arka Sowmya recorded the highest pod yield per ha (262.12 q) when sown on January $1^{\text {st }}$ and the plants were sprayed with Triacontanol $2 \mathrm{ppm}\left(\mathrm{V}_{4} \mathrm{~S}_{2} \mathrm{G}_{2}\right)$, followed by same variety with January $15^{\text {th }}$ sowing and the plants were sprayed with Triacontanol $2 \mathrm{ppm}\left(\mathrm{V}_{4} \mathrm{~S}_{3} \mathrm{G}_{2}\right)(237.94 \mathrm{q})$.

\section{References}

Abido, W.A.E. and Seadh, S.E. 2014. Rate of variations between field bean Cultivars due to sowing dates and foliar spraying treatments. Science International. 2(1): 112

Chaudhary, B.R., Sharma, M.D., Shakya, S.M. and Gautam, D.M. 2006. Effect of plant growth regulators on growth, yield and quality of chilli (Capsicum annuum L.) at Rampur, Chitwan. Journal of Instant Agriculture and Animal Science. 27: $65-68$

Das, S.S., Fakir, M.S.A., Ferdausi, A. and
Biswas, M.M.I. 2012. Morphological, growth and biochemical features of Dipogon lignosus (L.) Verdc. Journal of Bangladesh Agrilculture University. 10(1): 43-48.

Esakkiammal, B., Lakshmibai, L. and Sornalatha, S. 2015. Studies on the combined effect of vermicompost and vermiwash prepared from organic wastes by earthwarms on the growth and yield parameters of Dolichos lablab. Asian Journal of Pharma. Science and Technology. 5(4): 246-252.

Hussain, M.M. 2005. Yield and quality of Bush bean (Phaseolus vulgaris L.) genotypes as influenced by date of sowing. M.Sc. Thesis. Bangabandhu, Sheikh Mujibur Rahman Agricultural University, Gazipur, Bangladesh.

Joshi, S.K. and Rahevar, H.D. 2014. Effect of Dates of Sowing, Row Spacings and Varieties on Yield Attributes and Yield of Rabi Indian Bean (Dolichos lablab L.). Trends in Biosciences. 7(22): 3727-3732

Kharbamon, B., Jha, A.K., Verma, V.K., Choudhury, B.U. and Bidyut, C.D. 2016. Effect of planting time and phosphorus dosage on growth, yield and quality attributes of Indian bean (Lablab purpureus L.). Indian Journal of Hill Farming. 29: 65-71

Menon, K.K.G.and Srivastava,H. C. 1984 Increasing plant productivity through improved photosynthetic process. Indian Academic Science (Plant Science) 23: 359-78.

National Horticulture Board statistics 2017-18

Palakshi Borah, Sailaja, V., Chandrasekhar Rao, P. and Pratap Kumar Reddy, A. 2012. Response of tomato (Solanum lycopersicum L.) to potassium fertilization along with foliar application of potassium humate and triacontanol. Research Journal of ANGRAU. 40(3): 7981

Patel, A. M., Patel, P.S., Patel, P.G. and Patel, 
D.G. 2008.Production potential of different moth bean [Vigna aconitifolia (Jacq.) Marechal] varieties under north Gujarat condition. $3^{\text {rd }}$ National symposium on enhancing productivity, Nutritional security and export Potential through Arid Legumes. 28-30:66

Patel, B.V., Parmar, B.R., Parmar, S.B. and Patel, S.R. 2011. Effect of different spacings and varieties on yield parameters of cowpea (Vigna unguiculata (L.) Walp.). The Asian Journal of Horticulture. 6(1): 56-59

Prakash, J. and Ram, R.B. 2014. Genetic variability, correlation and path analysis for seed yield and yield related traits in french bean (Phaseolus vulgaris L.) under Lucknow conditions. International Journal of Innovative Science, Engineering and Technology. 1(6): 4150 .

Prakash, J., Ram, R.B. and Meena, M.L. 2015. Genetic variation and characters interrelationship studies for quantitative and qualitative traits in french bean (Phaseolus vulgaris L.) under Lucknow conditions. Legume Research. 38 (4): 425-433.

Rana, D.K. and Kumar. A. 2008. Performance of various French bean (Phaseolus vulgaris L.) genotypes under mid-hill condition of Garhwal Himalaya areas. Progressive Horticulture. 40(2): 184-186.

Ravinaik, K., Hanchinmani, C.N., Patil, M.G. and Imamsaheb, S.J. 2015. Evaluation of dolichos genotypes (Dolichos lablab L.) under north eastern dry zone of Karnataka. Asian Journal of Horticulture.
10(1): 49-52.

Setia, R.C., Setia, N. and Malik, C.P. 1991. Plant growth regulators: Overview and role in crop productivity. In: Recent Advances in Plant Biology, (Ed.) C.P.Malik and Y.P. Abrol. Narendra Publishing House, New Delhi. Pp. 417476.

Sharma, A., Sharma, M., Sharma, K.C., Singh, Y., Sharma, R.P. and Sharma, G.D. 2014. Standardization of sowing date and cultivars for seed production of garden pea (Pisum sativum var. Hortense L.) under north western Himalayas. Legume Research. 37(3): 287-293

Sharma, S.K. 1995. Response of triacontanol application on certain morphological characters, fruit and seed yield and quality of tomato seed. Annals of Agricultural Research. 16(1): 128-130

Singh, S.P. 2010. Response of plant growth regulator on growth and yield of fenugreek (Trigonella foenumgraecum L.). The Asian journal of Horticulture. 5(1): 234-236.

Surekha, 2006. Response of rajmash genotypes to time of sowing during rabi in the northern transitional zone of Karnataka. M. Sc. Thesis. University of Agricultural Sciences, Dharwad, Karnataka, India.

Vethamoni, I. P. and Natarajan, S. 2008.Effect of natural resources on plant growth, yield and quality in chilli cultivars (Capsicum annuum L.). The Asian Journal of Horticulture. 3(2): 319322.

\section{How to cite this article:}

Padma, E., K. Uma Jyothi, G. Ramanandam, P. Subbaramamma and Uma Krishna, K. 2020. Effect of Varieties, Dates of Sowing, Growth Regulators and their Interaction on Growth and Yield of Dolichos Bean (Lablab purpureus L.) During off Season under Coastal Andhra Pradesh Conditions. Int.J.Curr.Microbiol.App.Sci. 9(09): 933-942. doi: https://doi.org/10.20546/ijcmas.2020.909.115 